\title{
IMPLEMENTASI HAK REPRODUKSI PEREMPUAN DALAM PROGRAM KELUARGA BERENCANA BERDASARKAN UNDANG-UNDANG NOMOR 52 TAHUN 2009 TENTANG PERKEMBANGAN KEPENDUDUKAN DAN PEMBANGUNAN KELUARGA
}

\author{
Sri Mulyani \\ Email: srimulyanisst@gmail.com \\ Pegawai Dinas Kesehatan Kabupaten Karanganyar \\ Yovita A. Mangesti \\ Email: Mangestiyovita@gmail.com \\ Arief Suryana \\ Email: arsur15@yahoo.co.id, \\ Dosen Fakultas Hukum UNS Surakarta
}

\begin{abstract}
This paper is intended to know the implementation of Law No. 52 of 2009 on Population Development and Family Development in the enforcement of women's reproductive rights Indonesia in the policy of Family Planning and determine the factors that become an obstacle in the implementation of Law No. 52 of 2009 on Population Development and family Development in the enforcement of women's reproductive rights in family planning programs. Legal research is empirical research or non doctrinal with method approach qualitative research in Puskesmas Kebakkramat. The results showed that the implementation of the Law No. 52 Year 2009 on Population Development and Family Development with Reproductive Rights of Women conducted by Puskesmas Kebakkramat already well underway, in which medical personnel in health centers Kebakkramat providing information about contraceptives, providing extension, KB free sale, provide information that apply two children is better and the implementation of contraception in men. Barriers to implementation of the Law No. 52 of 2009 in efforts to uphold women's reproductive rights in Puskesmas Kebakkramat include the reduction of Field Officers Extension KB), participation Men in KB still low, especially Medical Operations Man, KB is active still dominated by methods injectable contraceptives, lack of public knowledge and just some people who are aware of the problem kindness of family planning programs.
\end{abstract}

Keyword: implementation; Family Planning Program; Reproduction Health

\begin{abstract}
Abstrak
Tulisan ini bermaksud mengetahui implementasi Undang-undang Nomor 52 Tahun 2009 tentang Perkembangan Kependudukan dan Pembangunan Keluarga dalam upaya penegakan hak reproduksi perempuan Indonesia dalam kebijakan program Keluarga Berencana dan mengetahui faktor-faktor yang menjadi penghambat dalam implementasi Undang-undang Nomor 52 Tahun 2009 tentang Perkembangan Kependudukan dan Pembangunan Keluarga dalam penegakan hak reproduksi perempuan dalam program keluarga berencana (KB). Penelitian hukum ini merupakan penelitian empiric atau non doktrinal dengan metode pendekatan penelitian kualitatif di Puskesmas Kebakkramat. Hasil penelitian ini menunjukkan bahwa implementasi dalam Undang-undang
\end{abstract}


Nomor 52 Tahun 2009 tentang Perkembangan Kependudukan dan Pembangunan Keluarga dengan Hak Reproduksi Perempuan yang dilakukan oleh Puskesmas Kebakkramat sudah berjalan dengan baik, dimana petugas kesehatan di Puskesmas Kebakkramat telah memberikan informasi tentang alat kontrasepsi, mengadakan penyuluhan, memberikan promosi KB gratis, memberikan informasi bahwa menerapkan dua anak lebih baik serta pelaksanaan kontrasepsi pada pria. Hambatan implementasi Undang-Undang Nomor 52 Tahun 2009 dalam upaya penegakan hak reproduksi perempuan di Puskesmas Kebakkramat antara lain adalah berkurangnya Petugas Lapangan Penyuluh KB (PLPKB), kesertaan KB Pria masih rendah terutama Medis Operasi Pria (MOP), peserta KB aktif masih didominasi oleh metode kontrasepsi suntik, rendahnya pengetahuan masyarakat dan hanya sebagian orang yang sadar akan masalah kebaikan program keluarga berencana.

Kata kunci: implementasi; program KB; kesehatan reproduksi

\section{A. Pendahuluan}

Program Keluarga Berencana (KB) merupakan salah satu kebijakan pemerintah Indonesia yang dipandang paling efektif untuk mengendalikan laju pertumbuhan penduduk. Tidak dipungkiri pula bahwa melalui program KB yang sudah berlangsung sejak era orde baru. Pandangan mengenai banyak anak banyak rezeki telah ditinggalkan oleh sebagian masyarakat. Banyak masyarakat semakin menyadari bahwa kebutuhan hidup saat ini semakin mahal, sehingga banyaknya anak akan menambah beban ekonomi tersendiri dalam kehidupan mereka. Sementara kondisi perekonomian saat ini cukup menyulitkan ditambah kebutuhan pendidikan, kesehatan dan kebutuhan dasar lainnya sangat sulit untuk tercukupi.

Pasal 1 ayat (8) Undang-undang Nomor 52 tahun 2009 tentang Perkembangan Kependudukan dan Pembangunan Keluarga mendefinisikan Keluarga Berencana adalah upaya mengatur kelahiran anak, jarak dan usia ideal melahirkan, mengatur kehamilan, melalui promosi, perlindungan, dan bantuan sesuai dengan hak reproduksi untuk mewujudkan keluarga yang berkualitas.

Dinamika kebijakan program KB sering menghasilkan fenomena dilematis dalam realisasi penegakan hak reproduksi sebagai hak dasar yang harus terpenuhi oleh masyarakat. Hal ini dapat dilihat dari munculnya ketimpangan dalam merealisasikan kewajiban pengendalian jumlah anak tersebut yang lebih dominan dibebankan pada pihak perempuan (istri). Hingga saat ini, belum ada keseimbangan antara jumlah akseptor KB pria dengan akseptor $\mathrm{KB}$ wanita.

Di beberapa kalangan masyarakat masih beredar stereotip bahwa program keluarga berencana hanya dilakukan oleh perempuan hendaknya harus dirubah, sebab pengadaan program keluarga berencana itu sendiri pada dasarnya berbasis gender. Berlaku kepada perempuan dan laki-laki dengan tujuan untuk mewujudkan keluarga kecil bahagia dan sejahtera seperti yang digaungkan oleh pemerintah selama ini. Keikutsertaan pria dalam ber-KB tak bisa ditunda-tunda lagi, karena akan memberikan kontribusi sangat besar terhadap pengendalian laju pertumbuhan penduduk dan penanganan kesehatan reproduksi, termasuk penurunan angka kematian ibu melahirkan dan angka kematian bayi. Tentu semua itu berpengaruh cukup besar dalam meningkatkan kualitas sumber daya manusia. Kebanyakan pria Indonesia masih enggan untuk ber-KB dengan berbagai alasan. Dari data Badan Kependudukan dan Keluarga Berencana Nasional (BKKBN), lebih dari 60 persen pasangan usia subur sudah mengikuti 
program KB, secara nasional keikutsertaan KB Pria kurang dari 3\% (Remon Hendra, 2014: 72).

Kesediaan perempuan untuk menjadi akseptor KB karena pada dasarnya, karena segala konsekuensi yang terjadi sebagai pertambahan jumlah anak lebih banyak dibebankan pada pundak perempuan. Segala proses reproduksi dari kehamilan, persalinan, menyusui dan merawat anak lebih banyak melibatkan peran istri yang tentunya hal tersebut tidak mudah. Ditambah lagi pandangan masyarakat yang lebih memposisikan perempuan sebagai kontributor terbesar dalam pendidikan anak tentunya semakin memperpanjang proses yang terjadi sebagai dampak bertambahnya jumlah anak.

Perempuan sebagai akseptor KB salah satu pertimbangannya adalah faktor umur dan kesehatan. Perempuan memiliki batasan umur untuk memiliki anak agar kesehatan anak dan ibu terjamin (Fatma Laili Khoirun Nida, 2013: 161). Segala proses reproduksi dari kehamilan, persalinan, menyusui dan merawat anak lebih banyak melibatkan peran istri yang tentunya hal tersebut tidak mudah. Ditambah lagi pandangan masyarakat yang lebih memposisikan ibu lebih berperan dalam pendidikan anak tentunya semakin memperpanjang proses yang terjadi sebagai dampak bertambahnya jumlah anak.

Di Indonesia, jaminan atas Hak Asasi Manusia diatur di dalam Undang-Undang Nomor 39 Tahun 1999 tentang Hak Asasi Manusia. Lebih khusus lagi, jaminan atas hak asasi perempuan dapat ditemui dalam Undang-Undang Nomor 7 Tahun 1984 tentang Penghapusan Diskriminasi Terhadap Perempuan. Undang-undang ini merupakan hasil rativikasi Convention on the Elimination of All From of Discrimination Against (CEDAW). Undang-undang tersebut menyatakan bahwa negara akan melakukan upaya semaksimal mungkin untuk menghapuskan segala bentuk diskriminasi terhadap perempuan, termasuk adanya kekerasan terhadap perempuan baik yang meliputi kekerasan di wilayah publik maupun di wilayah domestik. Dalam konvensi CEDAW ini dinyatakan bahwa negara-negara peserta, wajib mengubah hukum nasional agar menghapuskan diskriminasi terhadap perempuan dan melindungi hak perempuan. Hal ini berdampak kepada ketentuan-ketentuan yang dilahirkan pemerintah di Indonesia yang dituntut untuk memperhatikan asas non diskriminasi termasuk dalam peraturan tentang program Keluarga Berencana. Kebijakan Program KB tetap akan berjalan secara dilematis, disatu sisi hak reproduksi perempuan semestinya terlindungi dan tak tergerus hegemoni patriakhi.

Berdasarkan uraian diatas maka dalam tulisan ini hendak mengetahui implementasi Undang-Undang Nomor 52 Tahun 2009 tentang Perkembangan Kependudukan dan Pembangunan Keluarga dalam penegakan hak reproduksi perempuan dalam program keluarga berencana.

\section{B. Metode Penelitian}

Jenis penelitian dalam penelitian hukum ini adalah penelitian hukum empirik atau nondoctrinal research. Penelitian nondoktrinal menempatkan hasil pengamatan terhadap realitas-realitas sosial yang berupa pola-pola keajegan atau pola-pola hubungan entah yang korelasi entah yang kausal antara berbagai gejala yang memanifestasikan hadirnya hukum dialam kenyataan, sebagaimana yang bisa disimak oleh indra pengamatan (Soetandyo Wignjosoebroto, 2013: 132). Penelitian ini merupakan penelitian kualitatif. Metode analis yang digunakan dalam penelitian ini adalah teknik kualitatif dengan model analisis interaktif (Miles MB dan AM Huberman, 1992: 20). 


\section{Hasil Penelitian dan Pembahasan}

1. Kesesuaian Implementasi Undangundang Nomor 52 Tahun 2009 tentang Perkembangan Kependudukan dan Pembangunan Keluarga dengan Hak Reproduksi Perempuan

Salah satu bentuk implementasi dari Undang-Undang Nomor 52 tahun 2009 adalah dengan program safe motherhood. Safe motherhood merupakan upaya pemerintah untuk menurunkan angka kematian ibu serta meningkatkan derajat kesehatan ibu. Gerakan ini pertama kali dicanangkan pada International Conference on Safe Motherhood, Nairobi,1987. Program ini sendiri mulai dilaksanakan di Indonesia tahun 1988 dengan melibatkan secara aktif berbagai sektor pemerintah dan non-pemerintah, masyarakat, serta dukungan dari berbagai badan internasional. Empat pilar Safe Motherhood antara lain :

a. KB dapat menurunkan AKI karena dapat merencanakan waktu yang tepat untuk hamil,mengatur jarak kehamilan, menentukan jumlah anak. Sehingga tidak ada kehamilan yang tidak diinginkan, "4 terlalu”, yaitu terlalu muda, terlalu tua, terlalu sering hamil, dan terlalu banyak anak.

b. Pelayanan antenatal, tujuan pelayanan antenatal adalah untuk mencegah adanya komplikasi obstetri, mendeteksi komplikasi sedini mungkin dan penanganan secara memadai dan profesional.

c. Persalinan yang bersih dan aman, memiliki tujuan memastikan setiap penolong kelahiran/persalinan mempunyai kemampuan, ketrampilan, dan alat untuk memberikan pertolongan yang bersih dan aman, serta memberikan pelayanan nifas pada ibu dan bayi. d. Pelayanan obstetri esensial, memastikan bahwa tempat pelayanan kesehatan dapat memberikan pelayanan obstetri untuk risiko tinggi dan komplikasi tersedia bagi ibu hamil yang membutuhkan.

Perlindungan hak-hak reproduksi perempuan dalam Undang-Undang Nomor 52 tahun 2009 dapat diwujudkan melalui program keluarga berencana. Program keluarga berencana merupakan salah satu program pembangunan nasional yang sangat penting dalam rangka mewujudkan keluarga Indonesia yang sejahtera. Pelaksanaan program KB dipengaruhi sumber daya pelaksanaan program $\mathrm{KB}$, cara pandang masyarakat terhadap nilai anak dan kepesertaan $\mathrm{KB}$, serta pemakaian alat kontrasepsi. Kompetensi petugas dalam teknis pelayanan $\mathrm{KB}$ dan konseling sangat penting terkait pelayanan yang berkualitas. Pelaksanaan program KB di Indonesia harus dilaksanakan secara intensif agar masyarakat memperoleh pelayanan KB yang berkualitas. Perkembangan dan pembudayaan "semua keluarga ikut $\mathrm{KB}$ dengan memberikan pelayanan KB berkualitas memerlukan strategi yang tepat dengan memperhatikan tipologi budaya dan karakteristik masyarakat sasaran dan dengan memperhatikan hak kesehatan reproduksi individu.

Pusat Kesehatan Masyarakat menjadi salah satu institusi pemerintah yang bertugas dalam pelaksanaan pelayanan kesehatan masyarakat termasuk salah satunya adalah pelayanan program KB. Dalam pelaksanaan atau implementasi Undang-undang Nomor 52 Tahun 2009 tentang Perkembangan Kependudukan dan Pembangunan Keluarga dengan hak reproduksi perempuan maka Puskesmas Kebakkramat telah melaksanakan implementasi undang-undang tersebut 
dengan berdasarkan pada program pokok pelayanan kesehatan di Puskesmas yaitu Pelayanan(kesehatan ibu anak) KIA dan KB yang ditujukan untuk memberikan pelayanan kepada PUS (Pasangan Usia Subur) untuk ber-KB, pelayanan ibu hamil, bersalin dan nifas serta pelayanan bayi dan balita.

Puskesmas Kebakkramat dalam pelaksanaan KB menggunakan berbagai jenis alat kontrasepsi yang ada, misalnya adalah kontrasepsi tanpa alat (pil $\mathrm{KB}$ ataupun pemotongan atau pengikatan saluran telur dan sperma) dan kontrasepsi dengan alat (spiral dan keluarga berencana) dan juga KB bagi pria. Puskesmas Kebakkramat melakukan berbagai upaya dalam memberikan informasi bagi pasangan usia subur di wilayah kerja Puskesmas Kebakkramat melalui beberapa upaya antara lain mengadakan penyuluhan, memberikan promosi KB gratis dan menerapkan 2 anak lebih baik. Hal ini sesuai dengan Pasal 23 ayat 1 Undang-Undang No 52 Tahun 2009, bahwa Pemerintah dan pemerintah daerah wajib meningkatkan akses dan kualitas informasi, pendidikan, konseling, dan pelayanan kontrasepsi dengan cara:

a. Menyediakan metode kontrasepsi sesuai dengan pilihan pasangan suami istri dengan mempertimbangkan usia, paritas, jumlah anak, kondisi kesehatan, dan norma agama;

b. Menyeimbangkan kebutuhan laki-laki dan perempuan;

c. Menyediakan informasi yang lengkap, akurat, dan mudah diperoleh tentang efek samping, komplikasi, dan kegagalan kontrasepsi, termasuk manfaatnya dalam pencegahan penyebaran virus penyebab penyakit penurunan daya tahan tubuh dan infeksi menular karena hubungan seksual.
Pelaksanaan pelayanan KB di Puskesmas Kebakkramat telah dilakukan dengan baik, dimana bidan memberikan pelayanan $\mathrm{KB}$ suntik, pemasangan $\mathrm{KB}$ susuk atau intra uterine device (IUD)/ alat kontrasepsi dalam rahim (AKDR). Sebelum pelaksanaan pelayanan KB sudah didahului dengan pelaksanaan konseling terlebih dahulu sehingga calon akseptor memahami cara KB yang dipilih sebelum menentukan pilihannya. Hal ini sesuai dengan Pasal 20 Undang-Undang Nomor 52 Tahun 2009 menyebutkan, untuk mewujudkan penduduk tumbuh seimbang dan keluarga berkualitas, pemerintah menetapkan kebijakan keluarga berencana melalui penyelenggaraan program keluarga berencana dan pasal 21 ayat 1 Undang-Undang Nomor 52 Tahun 2009 tentang perkembangan kependudukan dan pengembangan keluarga, yaitu kebijakan pemerintah untuk membuat calon/ pasangan suami istri mengambil keputusan dan mewujudkan hak reproduksi yang bertanggungjawab mengenai : usia ideal perkawinan, usia ideal melahirkan, jumlah ideal anak, jumlah ideal kelahiran anak, dan penyuluhan kesehatan reproduksi.

Pelayanan KB di Puskesmas Kebakkramat sudah berjalan dengan baik karena petugas (bidan) sebelum pelaksanaan KB juga memberikan informasi terlebih dahulu tentang prosedur pilihan jenis alat kontrasepsi tentang keuntungan dan kerugian, kesesuaian jenis alat kontrasepsi yang digunakan, efek samping masing-masing alat kontrasepsi dan selanjutnya tindakan yang akan dilakukan sesuai dengan pilihan kontrasepsi.

Pada akhirnya implementasi atau pelaksanaan pelayanan KB di Puskesmas Kebakkramat telah dijalankan dengan baik karena petugas kesehatan di Puskesmas 
Kebakkramat telah memberikan informasi tentang alat kontrasepsi yang ada dengan berbagai keuntungan dan kelemahan dari masing-masing alat kontrasepsi yang dapat digunakan oleh calon akseptor. Hal ini berarti puskesmas dalam mensukseskan program KB sebagai implementasi dari UU Nomor 52 tahun 2009 telah dilakukan dengan baik. Hal ini telah sesuai dengan Pasal 21 ayat (1) UU Nomor 52 tahun 2009 yang menyatakan bahwa kebijakan keluarga berencana sebagaimana dimaksud dalam Pasal 20 dilaksanakan untuk membantu calon atau pasangan suami istri dalam mengambil keputusan dan mewujudkan hak reproduksi secara bertanggung jawab tentang: usia ideal perkawinan; usia ideal untuk melahirkan; jumlah ideal anak; jarak ideal kelahiran anak; dan penyuluhan kesehatan reproduksi.

Undang-Undang Nomor 52 Tahun 2009 bukan menekankan pada pelayanan kesehatan baik promotif, preventif, kuratif maupun rehabilitatif, tetapi cenderung difokuskan pada kualifikasi Keluarga Berencana sebagai suatu kebijakan dalam hal ini, penyelenggaraan program Keluarga Berencana dalam konteks pengendalian kuantitas penduduk. Untuk pelaksanaan ketentuan pasal 56 UndangUndang Nomor 52 Tahun 2009, telah dikeluarkan pula Peraturan Presiden Nomor 62 Tahun 2010 tentang Badan Kependudukan dan Keluarga Berencana Nasional yang mulai berlaku pada tanggal 13 Oktober 2010. Beberapa ketentuan yang relevan dalam Undang-Undang Nomor 52 Tahun 2009 berturut turut adalah :

a. Pasal 1 dan 5 yang mensyaratkan adanya perkawinan yang sah b. Pasal 23 dan 24 menyebutkan tentang metode kontrasepsi sesuai dengan pilihan pasangan suami istri

c. Pasal 24 ayat 2 disebutkan tentang pengenaan sanksi

d. Pasal 25 tentang hak dan kewajiban suami istri untuk pelayanan keluarga berencana sama

e. Pasal 26 tentang alat kontrasepsi yang berisiko terhadap kesehatan harus atas persetujuan suami istri setelah beroleh informasi serta

f. Pasal 29 ayat 2 tentang kewajiban Pemerintah dan Pemerintah Daerah menyediakan alat kontrasepsi bagi rakyat miskin.

Dalam kenyataannya penerapan peraturan perundang-undangan yang mengatur tentang sejumlah hak dan kewajiban pemerintah, pemerintah daerah, tenaga kesehatan dan tenaga lain yang terlatih serta warga masyarakat dalam konteks ini peserta KB khususnya di Puskesmas Kebakkramat Karanganyar sudah sepenuhnya ditaati. Dilihat dari perumusan ketentuan yang ada, perangkat yang mengatur tentang kesehatan reproduksi dan keluarga berencana ini cukup ideal dan sudah dilaksanakan dengan baik oleh petugas kesehatan yang ada di Puskesmas. Sekalipun dipertanyakan tentang kesiapan dari pihak pemerintah yang berkewajiban untuk menyediakan sumber daya kesehatan, akses dan atau fasilitas dalam pelayanan kesehatan dalam hal ini, pelayanan kesehatan reproduksi dan Keluarga Berencana, sehingga Puskesmas Kebakkramat telah melaksanakan hukum positif yang mengatur tentang Keluarga Berencana dengan baik karena telah menegakkan hak reproduksi perempuan. 
2. Faktor-faktor Penghambat Implementasi Undang-Undang Nomor 52 Tahun 2009 tentang Perkembangan Kependudukan dan Pembangunan Keluarga dalam Upaya Penegakan Hak Reproduksi Perempuan

Penduduk merupakan bagian dalam pembangunan di negara. Komponen terpenting dalam pembangunan tergantung dari kualitas penduduk. Masalah yang dihadapi di negara berkembang seperti Indonesia yaitu baby bom. Peledakan penduduk diperparah adanya stigma di masyarakat yang menurut filosofi jawa bahwa banyak anak, banyak rezeki oleh anggapan sebagian masyarakat dengan sumber daya manusia yang masih rendah. Stigma ini mengakibatkan meningkatnya angka kelahiran karena mereka menginginkan banyak anak. Peledakan penduduk tentu membawa tantangan dalam meningkatkan kesejahteraan masyarakat, menciptakan lapangan kerja, mengatasi masalah kemiskinan, meningkatkan mutu pendidikan dan kesehatan, meningkatkan infrastruktur, dan pelayanan publik.

Berdasarkan hal tersebut maka dalam mewujudkan pertumbuhan penduduk yang seimbang dan keluarga berkualitas dilakukan upaya pengendalian angka kelahiran dan penurunan angka kematian, pengarahan mobilitas penduduk, pengembangan kualitas penduduk pada seluruh dimensinya, peningkatan ketahanan dan kesejahteraan keluarga, penyiapan dan pengaturan perkawinan serta kehamilan sehingga penduduk menjadi sumber daya manusia yang tangguh bagi pembangunan dan ketahanan nasional, serta mampu bersaing dengan bangsa lain, dan dapat menikmati hasil pembangunan secara adil dan merata maka program Keluarga Berencana menjadi salah satu upaya dalam mengendalikan jumlah penduduk dan meningkatkan kualitas penduduk.

Hasil penelitian menunjukkan bahwa masih ada beberapa hambatan dalam pelaksanaan atau implementasi UndangUndang Nomor 52 Tahun 2009 tentang Perkembangan Kependudukan dan Pembangunan Keluarga dalam upaya penegakan hak reproduksi perempuan di Puskesmas Kebakkramat antara lain adalah sebagai berikut:

a. Semakin berkurangnya Petugas Lapangan Penyuluh KB (PLPKB),

b. Kesertaan KB Pria masih rendah terutama Medis Operasi Pria (MOP) karena masih kuatnya persepsi masyarakat tentang pelaksanaan program KB adalah urusan perempuan, sehingga peserta KB pria di Puskesmas Kebakkramat masih sangat rendah.

c. Peserta KB aktif masih didominasi oleh metode kontrasepsi suntik karena masyarakat di wilayah kerja Puskesmas Kebakkramat lebih menginginkan pelayanan KB yang bersifat praktis dan mudah didapat disekitar tempat tinggalnya,

d. Rendahnya pengetahuan masyarakat membuat sosialisasi petugas di lapangan kewalahan dalam melakukan penyuluhan kepada masyarakat karena masyarakat ekonomi menengah ke bawah masih menganggap program Keluarga Berencana tidak berguna dan hanya membuang-buang waktu saja

e. Hanya sebagian orang - orang yang sadar akan masalah kebaikan KB ini, banyak masyarakat yang belum mengetahui keuntungan dan kegunaan $\mathrm{KB}$, sedangkan $\mathrm{KB}$ sangat berguna untuk mengatur kelahiran anak yang banyak dan tidak terkendali. Kurangnya penyuluhan 
dan pembelajaran tentang $\mathrm{KB}$ membuat masyarakat buta akan pengetahuan tentang KB.

Untuk mengatasi adanya faktor penghambat dalam implementasi implementasi Undang-Undang Nomor 52 Tahun 2009 tentang Perkembangan Kependudukan dan Pembangunan Keluarga dalam upaya penegakan hak reproduksi perempuan di Puskesmas Kebakkramat adalah dengan adanya dukungan dan komitmen yang kuat dari pimpinan (Bupati, legislatif dan internal organisasi), pemantapan organisasi kelembagaan dan peningkatan pelaksanaan program Keluarga Berencana dengan menambahkan jumlah petugas lapangan Keluarga Berencana, semakin menambah mitra kerja agar jaringan untuk sosialisasi lebih luas, terus mensosialisasikan $\mathrm{KB}$ untuk pria terutama Medis Operasi Pria (MOP).

\section{Simpulan}

Simpulan dari hasil penelitian ini adalah sebagai berikut:

1. Implementasi dalam Undang-undang Nomor 52 Tahun 2009 tentang Perkembangan Kependudukan dan Pembangunan Keluarga dengan Hak Reproduksi Perempuan yang dilakukan oleh Puskesmas Kebakkramat sudah berjalan dengan baik, dimana petugas kesehatan di Puskesmas Kebakkramat telah memberikan informasi tentang alat kontrasepsi, mengadakan penyuluhan, memberikan promosi $\mathrm{KB}$ gratis, memberikan informasi bahwa menerapkan 2 anak lebih baik serta pelaksanaan kontrasepsi pada pria. Hal ini sesuai dengan Pasal 20 dan pasal 21 Undang-undang RI Nomor 52 Tahun 2009 tentang perkembangan kependudukan dan pengembangan keluarga, yaitu kebijakan pemerintah untuk membuat calon/ pasangan suami istri mengambil keputusan dan mewujudkan hak reproduksi yang bertanggungjawab mengenai : usia ideal perkawinan, usia ideal melahirkan, jumlah ideal anak, jumlah ideal kelahiran anak, dan penyuluhan kesehatan reproduksi

2. Hambatan dalam pelaksanaan atau implementasi Undang-Undang Nomor 52 Tahun 2009 tentang Perkembangan Kependudukan dan Pembangunan Keluarga dalam upaya penegakan hak reproduksi perempuan di Puskesmas Kebakkramat antara lain adalah berkurangnya Petugas Lapangan Penyuluh KB (PLPKB), kesertaan KB Pria masih rendah terutama Medis Operasi Pria (MOP) karena masih kuatnya persepsi masyarakat tentang pelaksanaan program $\mathrm{KB}$ adalah urusan perempuan, peserta KB aktif masih didominasi oleh metode kontrasepsi suntik karena masyarakat di wilayah kerja Puskesmas Kebakkramat lebih menginginkan pelayanan KB yang bersifat praktis dan mudah didapat disekitar tempat tinggalnya, rendahnya pengetahuan masyarakat membuat sosialisasi petugas di lapangan kewalahan dalam melakukan penyuluhan kepada masyarakat dan hanya sebagian orang yang sadar akan masalah kebaikan KB ini, banyak masyarakat yang belum mengetahui keuntungan dan kegunaan KB.

\section{E. Saran}

1. Puskesmas hendaknya memberikan pendidikan kesehatan tentang hak reproduksi perempuan perlu disampaikan kepada kaum laki-laki termasuk remaja laki-laki dan remaja perempuan, sehingga mereka dapat menghormati hak reproduksi perempuan dengan nyata sehingga hak reproduksi masing-masing dapat lebih dipahami oleh masyarakat. 
2. Pemerintah Daerah Kabupaten Karanganyar perlu mensosialisasikan peraturan tentang Keluarga Berencana dan kesehatan reproduksi kepada seluruh lapisan masyarakat, sehingga pengetahuan untuk mendapatkan hak reproduksi dapat dinikmati oleh seluruh perempuan yang pada akhirnya menjarangkan kehamilan bukan hanya berdasarkan kewajiban warga negara untuk mencapai jumlah penduduk yang ideal tetapi merupakan kesadaran untuk menjaga kesehatan reproduksinya yang menjadi hak asasi perempuan secara nyata.

\section{F. Daftar Pustaka}

A.A Gde Muninjaya. 2004. Manajemen Kesehatan. Jakarta : Penerbit Buku Kedokteran

Abdurrahman Ritonga, dkk. 2003. Kependudukan dan Lingkungan Hidup, Cetakan Kedua. Jakarta : Lembaga penerbit Fakultas Ekonomi Universitas Indonesia

Achmad Ali. 2002. Menguak Tabir Hukum (Suatu Kajian Filosofis dan Sosiologis). Jakarta: PT. Gunung Agung Tbk, Jakarta

Affandi, B. 2011. Buku Panduan Praktis Pelayanan Kontrasepsi. Jakarta : PT. Bina Pustaka
Alexandra Indriyanti Dewi. 2008. Etika dan Hukum Kesehatan. Yogyakarta : Pustaka Book Publisher, Yogyakarta

Anny Isfandyarie. 2006. Tanggung Jawab Hukum dan Sanksi bagi Dokter. Jakarta: Prestasi Pustaka, Jakarta

Arfan Ikhsan. 2010. Manajemen Rumah Sakit. Bandung : Graha Ilmu

Bubung Bunyamion. 2014. Isu Gender Dalam Program Keluarga Berencana. Jurnal Parallela, Vol 1, No 2

Remon Hendra. 2014. "Pemantapan Partisipasi Pria Dalam Program Keluarga Berencana." Jurnal Parallela. Vol 1, No 1

Fatma Laili Khoirun Nida. 2013. "Penegakan Hak Reproduksi Perempuan Dalam Kebijakan Keluarga Berencana di Indonesia." Palastren, Vol. 6, No. 1.

Miles MB dan AM Huberman. 1992. Analisis Data Kualitatif: Buku Sumber tentang Metode-Metode Baru (Qualitative Data Analysis:A Basic Book on New Methods), Jakarta : Universitas Indonesia.

Soetandyo Wignjosoebroto. 2013. RagamRagam Penelitian Hukum dalam Metode Penelitian Hukum:Konstelasi dan Refleksi. Jakarta : Yayasan Pustaka Obor Indonesia 